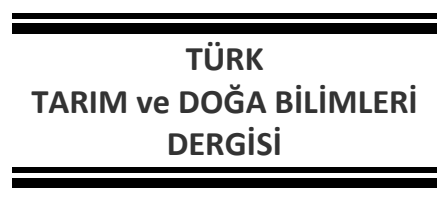

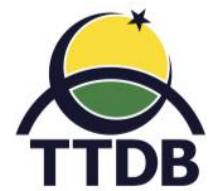

www.dergipark.gov.tr/turkjans

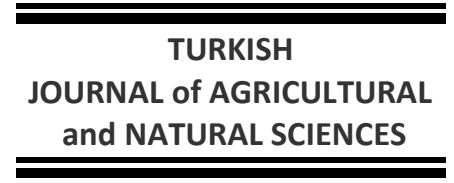

Araştırma Makalesi

\title{
Çanakkale Gökçeada'da Yetiştirilen Kalabaki Üzümünün Tane Yüzeyindeki Maya Çeşitliliğinin Tanımlanması ve Karakterizasyonu
}

\author{
Tülay TURGUT GENÇ*, Çağla ÇAKALOĞLU² \\ ${ }^{1}$ Çanakkale Onsekiz Mart Üniversitesi, Fen Edebiyat Fakültesi, Biyoloji Bölümü, Çanakkale, Turkey \\ ${ }^{2}$ Çanakkale Onsekiz Mart Üniversitesi, Fen Bilimleri Enstitüsü, Biyoloji Ana Bilim Dalı, Çanakkale, Turkey
}

*Sorumlu Yazar: tturgutgenc@comu.edu.tr

\section{Özet}

Üzümlerin olgunlaşmasında, tatlanmasında, şeker içeriğinin oluşmasında ve birçok fermente ürünün elde edilmesinde maya türlerinin önemli görevleri bulunmaktadır. Bağ alanının coğrafik konumuna ve üzüm çeşidine göre üzüm yüzeyinin maya çeşitliliği değişkendir. Çanakkale ilinin Gökçeada ilçesinde yetiştirilen Kalabaki üzümünün barındırdığı maya çeşitliliği rDNA gen bölgelerinin (ITS1-5.8S-ITS2) PCR-RFLP ve DNA dizi analizleri yapılarak belirlendi. Tanımlanan maya türlerinden $H$. uvarum maya türünün maya mikrobiyotasının yarısına hâkim olduğu, diğer maya türlerinin üzüm yüzeyinde dağılımlarının ise $\% 17,7$ A. pullulans, $\% 11,76$ C. carpophila, $\% 5,88$ M. pulcherrima, $\% 5,88$ S. bacillaris, $\% 5,88$ S. salmonicolor, $\% 2,94$ C. apicola ve $\% 2,94$ Z. obscura olduğu tespit edildi. Çalışmamız ile $Z$. obscura maya türü ilk defa, $C$. carpophila maya türü ise ikinci kez üzüm yüzeyinde tanımlandı. Kalabaki üzümünün tane yüzeyinde maya çeşitliliği fazla olmamakla beraber değişken türleri barındırdığı belirlendi.

Anahtar kelimeler: Kalabaki üzümü, maya mikrobiatası, RFLP, ITS.

\section{Identification and Characterization of Yeast Diversity on Berry Surface of Kalabaki Grape Grown in Gökçeada, Çanakkale}

\begin{abstract}
Yeast species have important roles in grape ripening and sweetening, formation of sugar content and the production of many fermented products. According to the geographical position of the vineyard and grape varieties the yeast diversity on grape berry surfaces is variable. PCR-RFLP analysis and DNA sequencing of rDNA gene regions (ITS1-5.8S-ITS2) were used for identification of yeast species isolated from Kalabaki grape variety grown in Gökçeada district of Çanakkale province. Among the identified yeast species, H. uvarum yeast strains covered half of grape surface microbiata. The percent distribution of other yeast species on the grape berry surface were determined as fallows: $17.7 \%$ A. pullulans, $11.76 \%$ C. carpophila, $5.88 \%$ M. pulcherrima, $5.88 \%$ S. bacillaris, $5.88 \%$ S. salmonicolor, $2.94 \%$ C. apicola ve $2.94 \%$ Z. obscura. C. carpophila yeast species was identified and reported for the second time by our work on the surface of grapes. In addition, Z. obscura yeast species was first described on the grape berry surface in our research. The diversity of yeast species on Kalabaki grape berries was not various, but the rare yeast species was recorded in yeast biota.
\end{abstract}

Key words: Kalabaki grape, yeast microbiata, RFLP, ITS.

Giriş

Ülkemizde yetiştirilen tahıl, sebze ve meyve gibi bitkisel ürünlerin üretimi devamlı artış göstermektedir. Bir önceki yıla göre tahıl ürünleri üretim miktarında \%2.4 oranında, sebze ürünlerinde $\% 1.8$ oranında ve meyve ürünlerinde
\%9.7 oranında artış gösterdiği TÜiK-Bitkisel Üretim İstatistikleri verilerinde rapor edilmiştir (TUIK, 2017). Bu verilere göre üzüm üretiminde bir önceki yıla göre \%5 oranında artış gözlenmiştir. FAO (Food and Agriculture Organization of the United Nations) ve OIV (International Organisation of Vine and 
Wine) gibi organizasyonların yayınlamış oldukları verilere göre Türkiye bağ alanlarına sahip ülkeler sıralamasında İspanya, Çin, Fransa ve İtalya'dan sonra dünyada 5. sırada, üzüm üretiminde ise 6 . sırada yer almaktadır (OIV, 2017; FAO-OIV Focus, 2016). OIV verilerine göre Türkiye sofralık üzüm veya yaş üzüm üretiminde dünyada 6 . sırada, kuru üzüm üretiminde ise 1. sırada bulunmaktadır. Üzüm üretiminde dünyada ilk sıralarda yer alan Fransa (\%99), İspanya (\%87) ve İtalya (\%85) gibi ülkeler ürettikleri üzümün çoğunluğunu şarap olarak değerlendirirken Türkiye için bu oran $\% 2$ olarak rapor edilmiştir (OIV, 2017).

Üzümlerin olgunlaşmasında, tatlanmasında, şeker içeriğinin oluşmasında ve birçok fermente ürünün elde edilmesinde maya türlerinin önemli görevleri bulunmaktadır. Mayalar tek hücreli mikroorganizmalar olup doğada belirli habitatlarda komüniteler halinde yayılış göstermektedir. Farklı birçok habitatta bulunan mayalar 'generalist' (geniş niş), spesifik habitatlarda bulunanlar ise 'spesiyalist' (dar niş) mayalar olarak tanımlanırlar. (Lachance ve Starmer, 1998). Üzüm yüzeyinde bulunan mayalar 'spesiyalist' mayalar olup, genellikle Saccharomyces ve non-Saccharomyces olarak gruplandırılır. Üzüm şırasının alkolik fermantasyonu karmaşık biyokimyasal bir süreç olup, fermantasyonun ilk aşamasında non-Saccharomyces türleri yoğun olarak bulunmaktadır. Fermantasyonun sonraki aşamalarında ise mikrobiyotaya, alkol toleransı yüksek olan Saccharomyces türleri hâkim olmaktadır. (Fleet, 2007; Fugelsang ve Edwards, 2007; Fleet, 1993; Pretorius, 2000; Fleet ve Heard, 1993).

Üzüm şırasında ve fermantasyonun ilk evrelerinde Hanseniaspora uvarum türü baskın olarak bulunurken, sonraki aşamalarda Candida, Rhodotorula, Pichia, Kluyveromyces ve Hanseluna cinslerine ait maya türleri bulunabilmektedir (Querol ve ark., 1990; Longo ve ark., 1991; Fleet ve Heard, 1993; Schütz ve Gafner, 1994). NonSaccharomyces olarak adlandırılan bu maya türleri, özellikle şarap aromasına ve kalitesine katkı sağlayan ester, alkol ve asit gibi sekonder metabolitlerin üretiminden sorumludur (Jolly ve ark., 2003).

Genel olarak üzüm yüzeyindeki maya çeşitliliği ve yoğunluğu tüm dünyada benzerlik gösterse de, bağ alanının coğrafi konumu, rakımı, sıcaklık, nem ve bölgenin aldığı yağış miktarı gibi dış faktörlere bağlı olarak farklılık gösterebilmektedir. (Amerine ve ark., 1967; Longo ve ark., 1991). M.Ö 2900 yıllarından beri bağcılık yapıldığı bilinen Çanakkale ilinin Gökçeada ilçesi iklimi, rüzgârı, arazinin tomografik yapısı ve toprak özelliği bakımından bağcılık için oldukça uygundur. Shiraz, Chardonnay, Cabernet Sauvignon, Merlot ve
Kalabaki Gökçeada'da üretilen üzüm çeşitlerindendir. Bunların arasından en meşhuru Kalabaki üzümüdür ve bu üzümden yapılan şarap Gökçeada Şarabı olarak bilinmektedir.

Kalampaki, Limnio, Lemnia, Limnio, Lemniotico, Limniona, Mavro, Nthourou Kara ve Ntoyrou Kara isimleriyle de bilinen Kalabaki üzümünün vatanı Gökçeada'nın güneybatısında bulunan Limni adasıdır. Bu üzümden elde edilen Limnio şarabının 2000 yıldan fazla bir zamandır var olduğu bilinmektedir. Limnio şarabının yapımında Kalabaki üzümü kullanılmasına rağmen artık bu üzüm çeşidi Limni adasında kaybolmaya yüz tutmuştur (Mac Neil, 2015).

Kalabaki üzüm taneleri küçük veya orta ölçekli, silindirik veya konik şeklindedir. Kabuğu koyu mavi renkte ve orta kalınlıkta olup renksiz olan etli iç kısmı yumuşak ve suludur. Kalabaki üzümü geç olgunlaşan bir üzüm çeşididir. Nisan ayının başlarında bitki örtüsü yeşillenmeye başlar ve üzümlerin olgunlaşması eylül ayında gerçekleşir. 'Gökçeada Koşullarında Organik Üzüm Yetiştiriciliğinde Bağ Zararlılarının Yönetimi' konulu bir TÜBITAK-TAGEM projesi kapsamında elde edilen sonuçlara göre zararlı ve avcı böceklerin sebep olduğu problemlere karşı en dirençli üzüm çeşidinin Kalabaki üzüm çeşidi olduğu tespit edilmiştir (Altındişli ve Özsemerci, 2012).

Türkiye'de gerek üzüm farklılıklarına göre gerekse coğrafi konuma göre üzüm yüzeyindeki maya çeşitliliğinin belirlenmesine yönelik çalışma sayısı oldukça azdır. Yapılan çalışmalarda üzümlerden izole edilen maya izolatlarının fermantasyon şırası üzerine ve şarap üretimi sırasında izole edilen maya izolatlarının teknolojik özellikleri ve öldürücü etkileri daha çok incelenmiştir (Özçelik ve Dönmez, 1993; Özçelik ve ark., 1996; Nurgel ve ark., 2005). Üzüm yüzeyindeki maya mikrobiyotasının şarabın kalitesini etkilediği bilinmektedir. Bu nedenle şarap yapımında kullanılan üzümlerin maya mikrobiyotasının belirlenmesi önem arz etmektedir. Çalışmamızda Çanakkale ilinin Gökçeada ilçesinde yetiştirilen Kalabaki üzümlerinin yüzey maya mikrobiyotasının moleküler yöntemler kullanılarak belirlenmesi ve daha önce yapılan çalışmalarda elde edilen türlerle karşılaştırılarak analiz edilmesi amaçlanmıştır.

\section{Materyal ve Yöntem Maya izolasyonu}

Kalabaki üzüm örnekleri Çanakkale'nin Gökçeada ilçesi Tepeköy Mevkiinde (40¹1'27.2" N ve $25^{\circ} 49^{\prime} 55.1^{\prime \prime}$ E) bulunan 'Nusretbey Şarapları'nın üretildiği Nusret Avcı'ya ait üzüm bağlarından olgunlaşma dönemi dikkate alınarak 2016 Eylül ayında toplandı. Aseptik koşullarda alınan Kalabaki üzüm örnekleri sodyum sitrat çözeltisi (\%2) 
içerisinde homojenize edilerek YGC (40 gr/l Yeast Extract Glucose Chloramphenicol Agar, \%0.1 Sodyum Propiyonat) besi ortamına ekimleri yapıldı ve $30{ }^{\circ} C^{\prime}$ de 3 gün inkübe edildi. Maya suşlarının koloni oluşturabilen birim değerleri (CFU/ml) hesaplandı ve farklı koloni morfolojisi gösteren maya suşları rastgele seçilerek YPD (10 gr/l Yeast Extract, $20 \mathrm{gr} / \mathrm{l}$ Bacto-peptone, $20 \mathrm{gr} / \mathrm{l}$ Agar, $2 \%$ Dextrose) besi ortamına aktarıldı. Maya suşları daha sonraki kullanımlar için $-80^{\circ} \mathrm{C}^{\prime}$ de saklandı.

\section{Genomik DNA izolasyonu ve PCR amplifikasyonu}

Kalabaki üzümlerinden izole edilen maya suşlarının genomik DNA izolasyonları Kristjuhan ve ark. (2011) tarafından geliştirilen LiOAC +SDS metodu kullanılarak yapıldı. İzole edilen genomik DNA, maya suşlarının ITS1-5.8S -ITS2 rDNA gen bölgelerinin amplifikasyonları için kullanıldı. PCR amlifikasyonunda mayalar için evrensel olan ITS1 (5'-TCCGTAGGTGAACCTGCGG-3') ve ITS4 (5'TCCTCCGCTTATTGATATGC-3') primerleri kullanıldı ve daha önce belirlenen PCR şartlarında gerçekleştirildi (White ve ark., 1990). PCR ürünleri agaroz jelde (\%1.5) elektroforez yapıldı ve fotoğraflandı. Elde edilen PCR ürünlerinin uzunlukları Gel-Pro Analyzer Version 4.0 programı kullanılarak belirlendi ve maya suşlarının PCR uzunluklarına göre gruplandırılması yapıldı.

\section{Restriksiyon profillerinin belirlenmesi ve DNA dizi analizi}

Kalabaki üzümlerinden izole edilen maya suşlarının TS1-5.8S-ITS2 rDNA gen bölgelerinin amplifikasyonu sonrası elde edilen PCR ürünleri kit (Thermo Scientific - K0702) kullanılarak saflaştırıldı. Farklı restriksiyon enzimleri (Hinfl, Haelll, Mspl, Alul ve $H$ hal) kullanılarak amplikonların kesimleri yapıldı ve agaroz jelde (\%2.5) görüntülendi. Elde edilen bantların büyüklüğü Gel-Pro Analyzer Version 4.0 programı kullanılarak belirlenerek maya suşları restriksiyon profiline göre yeniden gruplandırıldı.

Restriksiyon profili farklı olan her bir maya suşunun ITS1-5.8S rDNA-ITS2 rDNA bölgelerinin sekanslama işlemi hizmet alımı yoluyla yaptırıldı. Elde edilen DNA dizilerin benzerlik analizi NCBI (National Center for Biotechnology Information) servisi tarafından sunulan BLAST (Basic Local Alingment Search Tool) programı kullanılarak yapıldı. Maya suşlarının DNA dizileri Gen Bankası veri tabanına yüklendi.

\section{Filogenetik analizler}

Filogenetik analizler için, maya suşlarına ait diziler MEGA7.0 programının içinde yer alan ClustalX hizalama parametresine göre hizalandı. Maya suşları arasındaki filogenetik ilişkiler MEGA 7.0 içerisinde yer alan maksimum parsimoni metodu, Tree-Bisection-Reconnection (TBR) seçeneği kullanılarak belirlendi ve filogenetik ağaç oluşturuldu.

\section{Bulgular ve Tartışma}

Gökçeada'nın farklı bağ alanlarında Shiraz, Chardonnay, Cabernet Sauvignon ve Merlot gibi şaraplık üzüm çeşitleri yetiştirilmektedir. Kökeni Limni adası olan ve Gökçeada'da da tekrar üretilmeye başlanan diğer bir çeşit ise Kalabaki üzümüdür. Kalabaki üzümünün barındırdığı doğal maya mikrobiyotasının belirlemek için hasat döneminde toplanan üzüm örneklerinden 34 maya suşu izole edildi. Kalabaki üzüm yüzeyindeki maya yoğunluğu $1,04 \times 10^{4} \mathrm{CFU} / \mathrm{ml}$ olarak hesaplandı. İzole edilen maya suşları koloni morfolojilerine göre gruplandırıldığında Grup 1 (GK-1), Grup 2 (GK-2 ve GK-12), Grup 3 (GK-3, GK-6, GK-8, GK-13, GK-17, GK30), Grup 4 (GK-4, GK-5, GK-7, GK-9, GK-10, GK-11, GK-14, GK-18, GK-24, GK-25, GK-29), Grup 5 (GK-15, GK-16), Grup 6 (GK-19 ve GK-20), Grup 7 (GK-21), Grup 8 (GK-22 ve GK-23), Grup 9 (GK-26, GK-27), Grup 10 (GK-28) ve Grup 11 GK-31, GK-32, GK-33 ve GK-34) olmak üzere11 farklı grup elde edildi.

İzole edilen maya suşlarının genomik DNA izolasyonları yapılarak ITS1-5.8S-ITS2 rDNA gen bölgelerinin çoğaltılması ITS1 ve ITS4 evrensel primerler kullanılarak yapıldı. Elde edilen PCR ürünlerinin bant büyüklükleri hesaplanarak maya suşları PCR ürünlerinin büyüklüklerine göre gruplandırıldı. Maya suşlarının PCR büyüklüklerine göre gruplandırıldığında GK-1, GK-15, GK-16, GK-19 ve GK-20 maya suşlarının yaklaşık $450 \mathrm{bç}$ uzunluğunda olduğu ve birinci grubu oluşturduğu, GK-2, GK-12, GK-21, GK-22, GK-23, GK-26, GK-27 GK- 28, GK-31, GK-32, GK-33 ve GK-34 maya suşlarının yaklaşık $600 \mathrm{bç}$ uzunluğunda olduğu ve ikinci grubu oluşturduğu ve GK-3, GK-4, GK-5, GK-6, GK -7, GK-8, GK-9, GK-10, GK-11, GK-13, GK-14, GK17, GK-18, GK-24, GK-25, GK-29 ve GK-30 maya suşlarının yaklaşık 750 bç uzunluğunda olduğu ve üçüncü grubu oluşturduğu belirlendi.

Kalabaki üzümünden izole edilen tüm maya suşlarının ITS1-5.8S-ITS2 rDNA gen bölgeleri Hinfl, HaellI, Mspl, Alul ve Hhal restriksiyon enzimleri ile kesimleri yapıldı ve bant büyüklükleri hesaplanarak maya suşları oluşturdukları restriksiyon profillerine göre tekrar gruplandırıldı (Tablo 1). PCR ürünlerinin büyüklüklerine göre yapılan gruplandırmada birinci grupta yer alan 5 maya suşu (GK-1, GK-15, GK-16, GK-19 ve GK-20) 3 farklı restriksiyon profili gösterdi. $\mathrm{Bu}$ grupta yer alan tüm maya suşlarının Alul restriksiyon enzimi için kesim bölgesi içermediği görüldü. Benzer şekilde ikinci PCR grubunda yer alan 12 maya suşunun (GK-2, GK-12, GK-21, GK-22, GK23, GK-26, GK-27, GK-28, GK-31, GK-32, GK-33 ve GK-34) 4 farklı restriksiyon profili oluşturduğu 
görüldü. PCR ürünlerinin büyüklüklerine göre son grupta yer alan 17 maya suşunun (GK-3, GK-4, GK-5, GK-6, GK-7, GK-8, GK-9, GK-10, GK-11, GK-13, GK14, GK-17, GK-18, GK-24, GK-25, GK-29, GK-30) Haelll ve Mspl için kesim bölgesine sahip olmadığı, diğer restriksiyon enzimleri ile kesimi sonrasında da tek tip profil gösterdiği belirlendi.

Gökçeada Kalabaki üzümlerinden izole edilen maya suşlarına ait ITS1-5.8S-ITS2 rDNA gen bölgelerinin PCR-RFLP analizi sonucu 8 farklı restriksiyon profili elde edildi. ITS1-5.8S-ITS2 rDNA gen bölgelerinin restriksiyon analizi doğal ortamlardan izole edilen birçok maya suşunun ayrılması ve belirlenmesi amacıyla kullanılmaktadır (Carvalho ve ark., 2010; Diba ve ark., 2012). Koloni morfolojilerine ve restriksiyon profillerine göre oluşturulan her grubun farklı maya türünü temsil ettiği düşünülerek, morfolojik grubu ve restriksiyon profilini temsil eden toplam 14 maya suşu (GK-1, GK-6, GK-9, GK-12, GK-15, GK-19, GK-20, GK-21, GK22, GK-26, GK-28, GK-29, GK-30 ve GK-32) seçildi ve ITS1-5,8 rDNA-ITS2 DNA bölgelerinin nükleotid dizileri belirlendi. DNA dizilerinin benzerlik analizleri (DNA Sequence Similarity Analysis) NCBI servisinin sunduğu BLAST (Basic Local Alignment Search Tool) analiz programı kullanılarak yapıldı ve analizi yapılan suşlarla en yüksek benzerlik gösteren türler belirlendi. Bu maya suşlarının ITS1-5.8S-ITS2 rDNA gen bölgelerine ait diziler NCBI tarafından sunulan GenBank veri tabanına yüklenerek erişim numaraları (GENBANK Accession Number) Tablo 2 'de verildi. Kalabaki üzüm yüzeyinden izole edilen GK-1, GK-15, GK-21, GK-22 ve GK-32 maya suşlarının sırasıyla Candida apicola, Metschnikowia pulcherrima, Zalaria obscura, Sporidiobolus salmonicolor ve Candida carpophila maya türleriyle oldukça yüksek oranda benzerlik gösterdiği tespit edildi. Ayrıca, GK-6, GK-9, GK-29 ve GK-30 maya suşlarının Hanseniaspora uvarum maya türüyle, GK19 ve GK-20 maya suşlarının Starmerella bacillaris maya türü ile, GK-12, GK-26 ve GK-28 maya suşlarının Aerobasidium pullulans maya türü ile homoloji gösterdiği belirlendi. Morfolojik olarak Grup 1, Grup 5, Grup 6, Grup 7, Grup 8 ve Grup 11 içinde yer alan maya türlerinin moleküler tanımlanması sonrasında farklı türler olduğu belirlendi. Ancak Grup 2, Grup 9 ve Grup 10'da yer alan maya türlerinin morfolojik olarak farklı olmasına rağmen moleküler tanımlama sonrası aynı tür (A. pullulans) olduğu belirlendi. Benzer şekilde morfolojik gruplandırmada iki farklı grup oluşturan (Grup 3 ve Grup 4) maya suşları H. uvarum maya türü olarak tanımlandı. Bu durum mikroorganizmaların tanımlanmasında moleküler yöntemlerin kullanılmasının doğru identifikasyonların yapılabilmesi için oldukça önemli olduğunu göstermektedir.

Çizelge 1. Maya suşlarının restriksiyon sonrası fragman uzunlukları.

\begin{tabular}{|c|c|c|c|c|c|c|}
\hline \multirow{2}{*}{$\begin{array}{c}\text { PCR } \\
\text { uzunluğu } \\
(\sim \mathrm{bç})\end{array}$} & \multirow[b]{2}{*}{ Maya Suşu } & \multicolumn{5}{|c|}{ Restriksiyon kesimi sonrası fragman uzunluğu ( bç) } \\
\hline & & HaellI & Hinfl & Mspl & Alul & Hhal \\
\hline \multirow{3}{*}{450} & GK-1 & $400-70$ & $\begin{array}{c}235-116- \\
115\end{array}$ & - & - & $\begin{array}{c}\text { 200-185- } \\
70\end{array}$ \\
\hline & GK-15, GK-16 & $\begin{array}{c}300- \\
100\end{array}$ & $195-190$ & $\begin{array}{c}218- \\
110-61\end{array}$ & - & $\begin{array}{c}200-100- \\
100\end{array}$ \\
\hline & GK-19, GK-20 & - & $227-220$ & - & - & $\begin{array}{c}200-100- \\
100 \\
\end{array}$ \\
\hline \multirow{4}{*}{600} & GK-2, GK-12, GK-26, GK-27, GK-28 & $\begin{array}{l}435- \\
140\end{array}$ & $\begin{array}{c}291-170- \\
130\end{array}$ & $\begin{array}{l}275- \\
180- \\
135\end{array}$ & $385-192$ & $\begin{array}{c}180-175- \\
110-50\end{array}$ \\
\hline & GK-21 & $\begin{array}{c}473- \\
124\end{array}$ & $\begin{array}{c}305-156- \\
133\end{array}$ & $\begin{array}{c}480- \\
115\end{array}$ & $398-215$ & $\begin{array}{r}190-150- \\
145-110\end{array}$ \\
\hline & GK-22, GK-23 & $\begin{array}{c}400- \\
120-85\end{array}$ & $\begin{array}{c}291-170- \\
130\end{array}$ & $\begin{array}{c}310- \\
305\end{array}$ & $\begin{array}{c}338-127- \\
125\end{array}$ & $400-210$ \\
\hline & GK-31, GK-32, GK-33, GK-34 & $\begin{array}{c}390- \\
120-85\end{array}$ & $312-294$ & $\begin{array}{c}372- \\
160-60\end{array}$ & - & $\begin{array}{c}300-250- \\
50\end{array}$ \\
\hline 750 & $\begin{array}{l}\text { GK-3, GK-4, GK-5, GK-6, GK-7, GK-8, GK- } \\
\text { 9, GK-10, GK-11, GK-13, GK-14, GK-17, } \\
\text { GK-18, GK-24, GK-25, GK-29, GK-30 }\end{array}$ & - & $\begin{array}{c}340-198- \\
185\end{array}$ & - & $535-185$ & $\begin{array}{c}300-300- \\
100\end{array}$ \\
\hline
\end{tabular}


Gökçeada Kalabaki üzüm yüzeyinde maya türlerinin dağılımı incelendiğinde, $H$. uvarum maya türünün maya mikrobiyotasına \%50 oranında hâkim olduğu görüldü. Diğer maya türlerinin üzüm yüzeyinde dağılımları ise sırasıyla $A$. pullulans $(\% 17,7)$, C. carpophila $(\% 11,76)$, M. pulcherrima $(\% 5,88)$, S. bacillaris $(\% 5,88)$, S. salmonicolor $(\% 5,88)$, C. apicola $(\% 2,94)$ ve Z. obscura $(\% 2,94)$ olarak belirlendi (Şekil 1).

Taze şaraplık üzümlerin yüzeyinde ve şırasında $K$. apiculata, $M$. pulcherrima, $P$. membranifaciens, $C$. stellata, $C$. raghi, I. orientalis ve Rhodotorula sp. maya türleri dağılım göstermektedir (Fleet ve Heard, 1993; Boulton ve ark., 1996; Ribereau-Gayon ve ark., 2000; Fleet, 2003, 2008; Prakitchaiwattana ve ark., 2004; Jolly ve ark., 2006; Turgut Genç ve Çıldır, 2012). Çalışmamızda Candida sp., Metschnikowia sp. ve Hanseniaspora sp. cinslerine ait maya türlerinin Kalabaki üzüm yüzeyinde de bulunduğu belirlenmiştir. C. carpophila maya türünün üzüm yüzeyinde tanımlanması ilk kez Portekiz'e bağlı Azor adalarında 'Lajidos' olarak adlandırılan bölgede yetiştirilen üzümlerle yapılan çalışma ile belirlenmiştir (Drumonde-Neves ve ark., 2017). Bu türün üzüm yüzeyinden ikinci kez izole edilerek tanımlanması ise çalışmamız ile gerçekleştirilmiştir.

Z. obscura maya türü 'maya-benzeri fungus' filogenetik kökene (Dothideales) sahiptir. Z. obscura maya türü ilk defa Kanada ve Amerika'da evlerde kullanılan elektrik süpürgelerinin içindeki tozlardan izole edilerek tanımlanmıştır (Humphries ve ark., 2017). Bugüne kadar tanımlandığı herhangi bir gıda ürünü bulunmamaktadır. $Z$. obscura maya türünün çalışmamızda ilk defa üzüm yüzeyinden izole edilerek tanımlanması maya türünün kontaminasyon yoluyla üzüm yüzeyinde bulunabileceğini düşündürmektedir. Ancak üzüm örneklerinin toplanmasından izolasyon aşamasına kadar çalışma koşulları göz önüne alındığında bu olasılık oldukça düşüktür. Bu nedenle $Z$. obscura maya türü Kalabaki üzümünün doğal maya biyotasında bulunmakta olup ilk defa üzüm yüzeyinde çalışmamız ile tanımlanmıştır.

\section{Sonuç ve Öneriler}

Çalışmamı sonucunda özellikle fermentasyon basamağında yüksek derecede öneme sahip Saccharomyces sp. maya türleri izole edilememiştir. Bu maya türleri ağırlıklı olarak olgun veya yara almış tanelerde bulunduğundan ve özellikle fermentasyon basamağında alkole dirençli olduğundan dolayı izole edilebilmesi için özel farklı tekniklerin kullanılması gerekmektedir (Martini ve ark., 1996; Mortimer ve Polsinelli, 1999).

(Yeast-like fungi) olup $A$. pullulans ile aynı

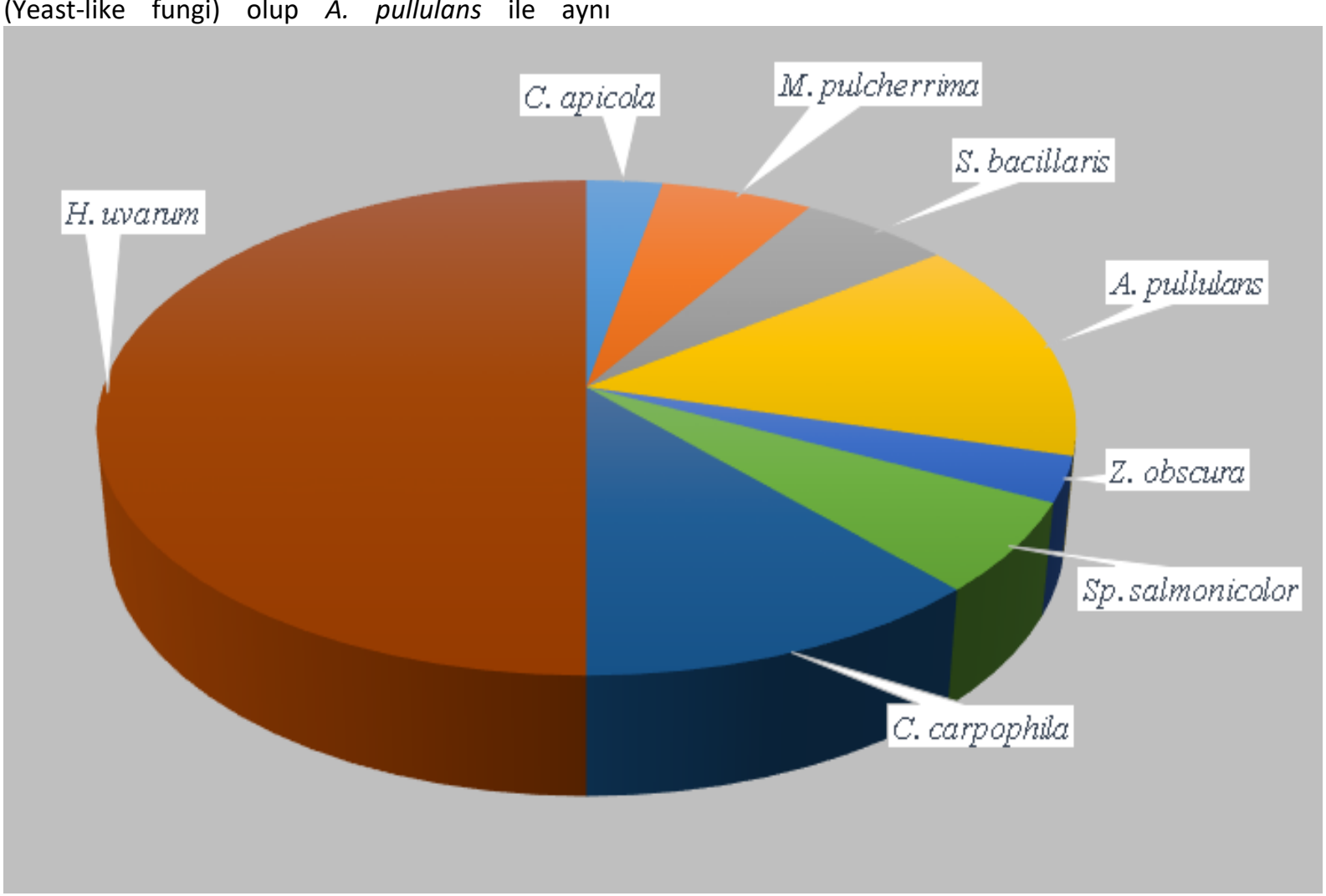

Şekil 1. Kalabaki üzüm yüzeyinden izole edilen maya türlerinin yüzdelik dağılımı. 


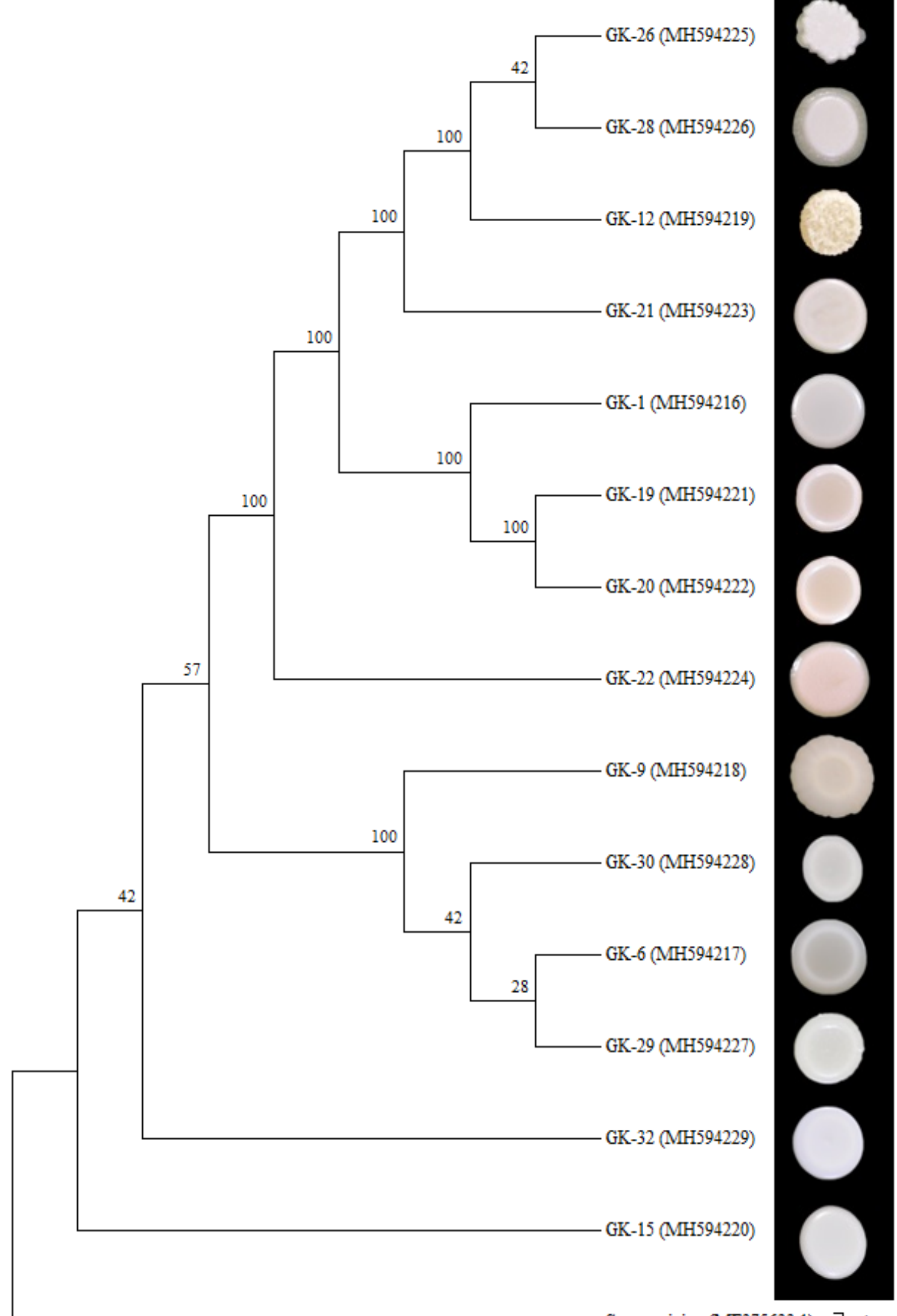

S. cerevisiae (MF375633.1) Joutgroup

Şekil 2. Üzüm yüzeyinden izole edilen maya türlerinin yakınlıklarını gösteren filogenetik ağaç (Maksimum parsimoni). 
Çizelge 2. Maya suşlarının BLAST sonrası eşleştiği maya türleri.

\begin{tabular}{|c|c|c|c|}
\hline Maya Suşu & Benzerlik & $\begin{array}{c}\text { Tanımlanan Maya Türü } \\
\text { (GenBank Erişim Numarası) }\end{array}$ & GenBank Erişim Numarası* \\
\hline GK-1 & $95 \%$ & $\begin{array}{l}\text { Candida apicola } \\
\text { (KY101939.1) }\end{array}$ & MH594216 \\
\hline GK-6 & $99 \%$ & $\begin{array}{l}\text { Hanseniaspora uvarum } \\
\text { KY103552.1 }\end{array}$ & MH594217 \\
\hline GK-9 & $99 \%$ & $\begin{array}{l}\text { Hanseniaspora uvarum } \\
\text { KY103552.1 }\end{array}$ & MH594218 \\
\hline GK-12 & $99 \%$ & $\begin{array}{l}\text { Aerobasidium pullulans } \\
\text { KY552634.1 }\end{array}$ & MH594219 \\
\hline GK-15 & $94 \%$ & $\begin{array}{c}\text { Metschnikowia pulcherrima } \\
\text { (FJ172528.1) }\end{array}$ & MH594220 \\
\hline GK-19 & $100 \%$ & $\begin{array}{c}\text { Starmeralla bacillaris } \\
\text { KY076623.1 }\end{array}$ & MH594221 \\
\hline GK-20 & $100 \%$ & $\begin{array}{c}\text { Starmeralla bacillaris } \\
\text { KY076623.1 }\end{array}$ & MH594222 \\
\hline GK-21 & $99 \%$ & $\begin{array}{c}\text { Zalaria obscura } \\
\text { NR153466.1 }\end{array}$ & MH594223 \\
\hline GK-22 & $100 \%$ & $\begin{array}{c}\text { Sporidiobolus salmonicolor } \\
\text { KU168775.1 }\end{array}$ & MH594224 \\
\hline GK-26 & $100 \%$ & $\begin{array}{l}\text { Aerobasidium pullulans } \\
\text { KU168775.1 }\end{array}$ & MH594225 \\
\hline GK-28 & $99 \%$ & $\begin{array}{l}\text { Aerobasidium pullulans } \\
\text { KT898760.1 }\end{array}$ & MH594226 \\
\hline GK-29 & $99 \%$ & $\begin{array}{l}\text { Hanseniaspora uvarum } \\
\text { KY103552.1 }\end{array}$ & MH594227 \\
\hline GK-30 & $100 \%$ & $\begin{array}{l}\text { Hanseniaspora uvarum } \\
\text { KY103554.1 }\end{array}$ & MH594228 \\
\hline GK-32 & $100 \%$ & $\begin{array}{l}\text { Candida carpophila } \\
\text { KY102015.1 }\end{array}$ & MH594229 \\
\hline
\end{tabular}

Koloni morfoloji grubunu ve restriksiyon profilini temsil eden 14 maya suşunun ITS1-5,8 rDNA-ITS2 DNA bölgelerinin nükleotid dizileri kullanılarak maksimum parsimoni ağacı oluşturuldu (Şekil 2). Morfolojik olarak birbirlerinden ayrılan maya suşlarının belirlenmesine olanak sağladığından bootstrap değerlerinde yüzdelik sınırlaması yapılmadı. Filogenetik ağaç incelendiğinde $M$. pulcherrima maya türünün (GK15) diğer maya türlerinin hepsi ile ortak dallanma noktasına sahip olduğu ve filogenetik ağacın ilk başlarında diğer türlerden ayrıldığı gözlendi. $A$. pullulans maya türünün $Z$. obscura maya türüyle, $M$. pulcherrima maya türünün $C$. carpophila maya türüyle, $C$. apicola maya türünün $S$. bacillaris maya türüyle ortak filogenetik dallanma noktasına sahip olduğu belirlendi. A. pullulans olarak tanımlanan GK-12, GK-26 ve GK-28 maya suşlarının koloni morfolojilerinde gözlenen farklılığın filogenetik ağaçtaki dallanma modeli ile benzer olduğu tespit edildi. Benzer sonuç $H$. uvarum maya türünde de tespit edildi. Aynı türün koloni morfolojilerinde gözlenen farkılığın filogenetik ağaçta da farklı dallanma noktaları oluşturduğu gözlendi.
Gökçeada'nın farklı bağ alanlarında Shiraz, Chardonnay, Cabernet Sauvignon ve Merlot gibi şaraplık üzüm çeşitleri yetiştirilmektedir. 'Limnio Şarabı' veya 'Gökçeada Şarabı' olarak bilinen şarabın yapımında kullanılan Kalabaki üzümü de yeniden adada yetiştirilmeye başlanmıştır. Kalabaki üzümünün barındırdığı maya mikrobiyotası bilinmediği gibi şarabın olgunlaşmasına ve aromasına katkıda bulunan non-Saccharomyces maya türleri de bilinmemektedir. Yürütülen çalışma sonucunda Gökçeada'ya özgü Kalabaki üzüm yüzeyinde $C$. apicola, M. pulcherrima, S. bacillaris, $A$. pullulans, Z. obscura, S. salmonicolor, C. carpophila ve $H$. uvarum türlerinin bulunduğu tespit edildi. $A$. pullulans ve $H$. uvarum maya türlerine ait suşların koloni morfolojilerinde gözlenen farklılıkların filogenetik ağaçtaki dallanma noktaları ile örtüştüğü tespit edildi. Z. obscura maya türü ilk defa üzüm yüzeyinden izole edilerek tanımlandı. Z. obscura maya-benzeri fungus (Yeast-like fungi) olup $A$. pullulans ile aynı filogenetik kökene (Dothideales) sahiptir. C. carpophila maya türü ise Azor adalarında üretilen üzümlerden sonra ikinci kez Kalabaki üzüm yüzeyinde rapor edildi. 


\section{Kaynaklar}

Altındişli, Ö., Özsemerci, F. 2012. Gökçeada'da Organik Üzüm Yetiştiriciliğinin Geliştirilmesi Alt Proje: Gökçeada Koşullarında Organik Üzüm Yetiştiriciliğinde Bağ Zararlılarının Yönetimi, TUBITAK-TAGEM.

Amerine, M.A., Berg, H.W.,, Cruess, W.V. 1967. The Technology of Winemaking (2nd ed). The AVI Publishing Company, Inc., Connecticut.

Boulton, R.B., Singleton, V.L., Bisson, L.F., Kunkee, R.E. 1996. Principles and Practices of Winemaking. Chapman \& Hall, New York.

Carvalho, C.M., Meirinho, S., Estevinho, M.L.F., Choupina A. 2010. Yeast species associated with honey: Different identification methods. Archivos de Zootecnia, 59(225): 103-113.

Diba, K., Namaki, A., Ayatolahi, H., Hanifian, H. 2012. Rapid identification of drug resistant Candida species causing recurrent vulvovaginal candidiasis. Medical Mycology Journal, 53: 193-198.

Drumonde-Neves, J., Franco-Duarte, R., Lima, T., Schuller, D., Pais, C. 2017. Association between grape yeast communities and the vineyard ecosystems. PLoS One. 12(1): e0169883.

FAO-OIV Focus, 2016. Table and Dried grapes. http://www.fao.org/3/a-i7042e.pdf (Erişim tarihi: 05.07.2018).

Fleet, G.H. 1993. The Microorganisms of Winemaking - Isolation, Enumeration and Identification. "Alınmıştır: Wine Microbiology and Biotechnology (ed) Fleet, G.H. Harwood Academic Publishers, Switzerland, 1-25.

Fleet, G.H., Heard, G.M. 1993. Yeasts Growth During Fermentation. "Alınmıştır: Wine Microbiology and Biotechnology (ed) Fleet, G.H., Harwood Academic Publishers, Switzerland, 27-54.

Fleet, G.H. 2007. Wine. "Alınmıştır: Food microbiology: Fundamentals and Frontiers (3rd ed.) (ed) Doyle, M.P. ve Beuchat, L.R., Washington, DC: ASM Press, 863-890.

Fleet, G.H. 2008. Wine yeasts for the future. FEMS Yeast Research, 8: 979-995.

Fugelsang, K.C., Edwards, C.G. 2007. Wine Microbiology: Practical Applications and Procedures. New York, NY: Springer, 394 s.

Humphries, Z., Seifert, K.A., Hirooka, Y., Visagie, C.M. 2017. A new family and genus in Dothideales for Aureobasidium-like species isolated from house dust. Ima Fungus, 8(2): 299-315.
Jolly, N.P., Augustyn, O.P.H., Pretorius I.S. 2003. The effect of non-Saccharomyces yeasts on fermentation and wine quality. South African Journal of Enology and Viticulture, 24: 55-62.

Jolly, N.P., Augustyn O.P.H., Pretorius I.S. 2006. The role and use of non-Saccharomyces yeasts in wine production. South African Journal for Enology and Viticulture 27: 15-39.

Kristjuhan, A., Lõoke, M., Kristjuhan K. 2011. Extraction of genomic DNA from yeasts for PCR-based applications. Biotechniques, 50(5): 325-328.

Lachance, M.A., Starmer W.T. 1998. Ecology and Yeasts. "Alınmıştır: The Yeasts, a Taxonomic Study, (4th ed.) (ed.) Kurtzman, C. P., J.W., Elsevier, Amsterdam, Netherlands, 21-30.

Longo, E., Cansado, J., Agrelo, D., Villa, T.G. 1991. Effect of climatic conditions on yeast diversity in grape musts from Northwest Spain. American Journal of Enology and Viticulture, 42: 141-144.

Mac Neil, K. 2015. The Wine Bible. New York: Workman Publishing, $1008 \mathrm{~s}$.

Martini, A., Ciani, M., Scorzetti, G. 1996. Direct enumeration and isolation of wine yeasts from grape surfaces. American Journal of Enology and Viticulture, 47: 435-440.

Mortimer, P., Polsinelli, M. 1999. On the origins of wine yeast. Research in Microbiology, 68: 4884-4893.

Nurgel, C., Erten, H., Canbaş, A., Cabaroğlu, T., Selli, S. 2005. Yeast flora during the fermentation of wines made from Vitis vinifera L. cv. Emir and Kalecik Karası grown in Anatolia. World Journal of Microbiology and Biotechnology, 21:1187-1194.

OIV, 2017. 2017 World Vitiviniculture Situation; OIV Statistical Report on World Vitiviniculture. file:///C:/Users/TTG/Desktop/cagla\%20pap er/oiv-en-bilan-2017.pdf (Erişim tarihi: 05.07.2018).

Özçelik, F., Dönmez, S. 1993. Killer yeasts and the determination of killer characters of some yeasts. Doğa- Turkish Journal of Biology, 17:1-4.

Özçelik, F., Türkmen, U., Ateş, S. 1996. Farklı bölgelerden izole edilen şarap mayalarının killer özelliklerinin belirlenmesi. Turkish Journal of Biology, 20(3): 241-249.

Prakitchaiwattana, C.J., Fleet, G.H., Heard G.H. 2004. Application and evaluation of denaturing gradient gel electrophoresis to analyse the yeast ecology of wine grapes. FEMS Yeast Research, 4: 865-877.

Pretorius, I.S. 2000. Tailoring wine yeast for the new millennium: novel approaches to the ancient art of winemaking. Yeast, 16: 675-729. 
Querol, A., Jiménez, M., Huerta, T. 1990. Microbiological and enological parameters during fermentation of musts from poor and normal grape harvests in the region of Alicante (Spain). Journal of Food Sciences, 55: 1603-1606.

Ribéreau-Gayon, P., Dubourdieu, D., Donèche, B., Lonvaud, A. (Eds.) 2000. Cytology, Taxonomy and Ecology of Grape and Wine Yeast. "Alınmıştır: Handbook of Enology, John Wiley and Sons, West Sussex, England, 1-49.

Schütz, M., Gafner, J. 1993. Analysis of yeast diversity during spontaneous and induced alcoholic fermentations. Journal of Applied Bacteriology, 75:551-558.
Turgut Genç, T. ve Çıldır, ì. 2012. bozcaada üzüm çeşitleri üzerinde non-Saccharomyces mayaların dağılımı. Biyoloji Bilimleri Araştırma Dergisi, 5 (1): 115-120.

TÜik, 2017. Haber Bülteni. Bitkisel Üretim İstatistikleri. Sayı 24581, http://www.tuik.gov.tr/PreHaberBultenleri. do?id=24581 (Erişim tarihi: 05.07.2018).

White, T.J., Bruns, T., Lee, S., Taylor J. 1990. Amplification and Direct Sequencing of Fungal Ribosomal RNA Genes for Phylogenetics. "Alınmıştır: PCR Protocols: A Guide to Methods and Applications (ed) Innis, M.A., Gelfand, D.H., Sninsky, J.J. ve White, T.J., Academic Press, San Diego, California, USA, 315-322. 